\title{
Lo improductivo, en los mercados de la industria audiovisual
}

\section{(4) Lucas Martinelli* (UBA/IIEGE/UNTREF)}

En esta intervención en el debate de la revista Mora dedicado a los Fráxitos de la disidencia sexual en la época de la globalización neoliberal, me interesa reflexionar sobre los vínculos entre el deseo minoritario y los espacios del mercado audiovisual para explorar, desde la emergencia de algunos objetos de la industria cultural, la aparición posible y deseable de una radicalidad política ligada a las sexualidades.

En su vertiente crítica, uno de los aspectos centrales de la indagación queer se basa en un imperativo de orden político que -como horizonte ideal hacia el que se deberían construir las imágenes en los lazos con el imaginario- se podría expresar con la díada: no producir / no reproducir. Se trata de las condiciones y modos de vida en común que, regladas por la sociedad capitalista, cis, hetero y homonormada, producen diversas formas de exclusión sobre los sujetos, víctimas en grados diferentes de una exposición a la violencia social permanente y sistémica. La compilación de artículos que realizaron María Victoria Dahbar, Alberto Canseco y Emma Song (2017) se interroga en este sentido y procura dar cuenta de los procesos de desposesión, interdependencia y precariedad con los que los cuerpos son enmarcados, y desmarcados, por los ritmos del neoliberalismo. Las perspectivas de las identidades sexuales demandan nuevas formas de radicalidad política porque se encuentran signadas por una asimilación al sistema capitalista que, desde una perspectiva queer, debería ser siempre cuestionada (Alderson, 2016). Ante los recientes avances de las políticas de derecha en el territorio mundial, esta preocupación tiene en diversas localizaciones resonancias urgentes.

El panorama global demuestra que es preciso situar una interpretación de lo queer como: "una forma de ubicarse en los debates sobre sexualidades y género, para observar sus «márgenes», normas y hegemonías en los diferentes espacios que habitamos real y simbólicamente" (Travéz, Castellanos y Viteri, 2013: 10). De este modo, se sigue que la potencia política de la sexualidad que se pretenda radical apunta a desorganizar los marcos con los que percibimos el mundo y, si no logran transformarlos, al menos desestabilizarlos, pues la política, desde la conceptualización de Jacques Rancière (2013: 61), viene a ser la actividad que reconfigura los marcos sensibles en el seno de los cuales se pueden definir los objetos comunes. El equilibrio de las imágenes de la industria cultural contemporánea con el imperativo al consumo lo convierten tanto en una reproducción de los criterios del mercado, como en una serie formativa de los modos de relacionamiento sexo-afectivo. Las relaciones estándar permiten elegir entre los catálogos de los sitios globales, que son los nuevos espacios subjetivos, la única relación que vale: la concerniente a la tríada cuerpo-home banking-dispositivo online.

\author{
Lucas Martinelli es tesista \\ doctoral en Estudios de Género y \\ licenciado en artes por la Facultad de \\ Filosofía y Letras de la Universi- \\ dad de Buenos Aires. Docente de \\ "Análisis de películas y críticas \\ cinematográficas" en UBA y de \\ “Imágenes del género" en UNTREF.
}


1. El nombramiento "Carlos Jauregui" a la estación de la línea del subte "H" de la Ciudad de Buenos Aires presenta un claro ejemplo de aquello que se denomina pinkwashing. Esta inscripción simbólica en la ciudad parece constituir, antes que un monumento a la lucha de la comunidad LGBTIQ, un modo de expiar los distintos modos en los que las acciones gubernamentales se van desentendiendo de la causa. Es paradójico que en paralelo a que se hace el nombramiento, se afiance un colectivo que lleva el nom bre de una travesti “L "L yo cuerpo trans racial (y horizonte político), es antitético al cuerpo de varón cis blanco de Jauregui. Estas figuras loables, a pesar de haber compartido la lucha política por los derechos, representan grados muy distintos de resistencia al sistema.
Desde una perspectiva actual y contextual, los fráxitos de la disidencia sexual y, particularmente, la diligencia de las batallas de la teoría queer, están más que nunca a prueba. En esta nueva etapa histórica para Argentina, donde los derechos de las minorías no están legitimados por el poder gubernamental, la atmósfera, entre extraña y siniestra, subraya la fragilidad de los reconocimientos adquiridos. Las muertes trans y los actos de odio cobran una cotidianeidad apabullante y se acompañan de cierto envalentonamiento revanchista respecto de lo que puede ser opinado en público. La represión a la protesta y manifestación social como hecho concreto, si bien en el pasado reciente también existía, vuelve a tomar el centro de la escena de la ciudad, ${ }^{1}$ dando cuenta de que las cosas que ocurren en los márgenes pueden recrudecerse.

El crítico brasileño Silviano Santiago (2006: 132) sugirió que la lucha política de los grupos minoritarios por la búsqueda de una identidad propia pasaba necesariamente por la investigación y recuperación de los objetos de la cultura que habían sido juzgados como menores por la cultura moderna (y la perspectiva academicista) a partir de sus pautas de evaluación. En resonancia con ese interés en la búsqueda de objetos de la cultura que estarían fuera de los valores canónicos, es posible pensar los objetos de la industria cultural que, en cierta medida disponibles y al alcance, están en proceso de construcción de un nuevo marco social de normalidad queer. Al mismo tiempo estos objetos constituyen, como respecto a la televisión lo ha manifestado Gilles Deleuze (1995), una proliferación sin freno de la técnica en las sociedades de control que va en detrimento del potencial crítico de las imágenes, en este caso, sexualizadas.

\section{La libertad de elegir}

El problema en cuestión es que la mayor visibilidad trae aparejado un mayor control sobre lo visible. En el estado de cosas actual, cada dato que ingresamos a la red es una contribución, mínima pero estable, respecto a la producción estadística sobre lo que se ve. El riesgo no es el ver en sí, sino esa medición que el poder utiliza gracias al ver sistemático: todos esos clikcs desde los que nos retroalimentamos con las pantallas. Podría plantearse un horizonte para las disidencias sexuales con relación a las imágenes de la industria cultural, en el que sea innecesario escrutar las representaciones en búsqueda de imágenes negativas, positivas o existentes sobre sujetos identitarios. Por ahora, el sistema construye, como si se tratara de la época de oro de los estudios de Hollywood, géneros diferenciados, no del todo explícitos, en los que se sugieren determinadas probabilidades de gusto según los productos escogidos y sus alianzas temáticas.

Uno de estos sistemas de imágenes a los que hago referencia es Netflix. Esta plataforma online que permite, a través del registro y pago, el acceso a diferentes series y películas se ha convertido rápidamente en un medio masivo de consumo. La pregunta sobre los nuevos modos de mirar es acompañada por una sospecha sobre la supuesta apertura a la libertad de elección (que siempre se dará en términos del capital). Sin duda, esta nueva versión de la técnica es otro mecanismo de subjetivación y poder que, como nos muestra la coyuntura política actual, es un marco siempre frágil a punto de quebrarse, particularmente cuando esos límites en los que la integración es tolerancia sostienen las identidades excéntricas que están integradas en lo económico.

La serie Please like me (2013) de Matthew Saville ${ }^{2}$ pone a Josh (Josh Thomas, su creador) en un ámbito reducido de relaciones familiares y amistosas. Si bien el vínculo privilegiado con el hospital psiquiátrico podría plantear una narración disruptiva sobre cierto sentido común, cada programa repasa los puntos nodales de las modas culinarias y los rasgos de las vidas integradas a determinado tipo de consumo enfatizado
2. Se escoge utilizar los nombres de los directores de las series como rasgo de autoría, aunque esto nstituya una problema particular por los títulos citados. 
por las elecciones "alternativas" que se convierten en signos de distinción. Esa "vuelta a lo natural" que construye la representación se adecúa a la moda neoliberal de la sociedad Whole Foods Market ${ }^{3}$ y reproduce en los decorados los nuevos espacios multinacionales (cadenas como Starbucks o Le pain cotidienne).

El programa de televisión RuPaul's Drag Race desde el año 2009 monta la competencia entre diversas drag queens por ganar un premio en dólares y una colección de cosméticos con un formato de reality show. Si bien aparece una apelación al amor con el que cada marica soñadora teje su sueño drag en el anhelo del éxito, el problema allí es justamente ese modelo del éxito. Una especie de talk show donde la carrera se compone de pequeños detalles, imprime no simplemente una reafirmación de los lugares destinados a quienes van a perder y ganar el juego, sino particularmente una cuestión acuciante en el lenguaje audiovisual: la veloz vorágine del glamour es una práctica de la crueldad definitoria de los límites del adentro y el afuera. El multiculturalismo producido desde la integración (drags latinas, negras y gordas) es una modulación más de la buena conciencia sobre las "libertades para ser diferente".

Fuera del universo Netflix, dos series de grandes productoras audiovisuales coquetean con el feminismo. The handmaids tale (2017), de Bruce Miller, desde los tópicos que el patriarcado y la mistificación femenina produce entre madres y prostitutas. Manifestados en el destino de las mujeres esclavas a los prostíbulos o los espacios de las criadas reproductoras, el planteo emancipador del libro de Margaret Atwood se actualiza para incorporar los contextos actuales de la disidencia sexual. Una escena tematiza directamente este proceso de fragilidad sobre el que me interesa indagar. En esta sociedad distópica, el presente se reconstruye con un flashback que muestra a la protagonista y su amiga en una manifestación a favor de los derechos que las comunidades queer han perdido. En medio de la protesta, desde un punto de vista subjetivo, sostenido en toda la serie, comienza la represión policial. Ellas logran escapar con dificultad. El lugar donde se esconden es un bar del mismo estilo de cadenas multinacionales de restaurantes citados anteriormente. Parece ser que no hay otro cobijo que el que ofrece el mercado. Por otro lado, Big little lies (2017), de Jean-Marc Vallée, retrata en los paisajes de la élite de Montecarlo, California la vida de un grupo de mujeres para mostrar, en el final, una alianza femenina contra un marido golpeador. Es muy difícil no pensar en la interseccionalidad, como ese cruce de variables tan decisivas para la vida como la clase y la raza, para considerar que el escape a una situación de violencia de género no se produce tan fácilmente por la determinación libre de una subjetividad liberal.

Lo improductivo es aquello que no sirve a las lógicas del poder. Adrián Cangi (1996: 81) analiza la ambición de la poesía de Néstor Perlongher desde un exceso deseante en el que la "sexualidad improductiva" construye un tartamudeo que atenta, en su carácter de residuo, contra la ley productiva y funcional de los órganos, de sus imaginarios normativos y sus potencias. Lo más radical del deseo minoritario y su producción simbólica está en su freno productivo, resistente a los órdenes tradicionales del sistema. Es necesario rescatar en las imágenes atisbos de resistencias, volver a ver cada objeto de la industria cultural en los que aparecen los términos de la diferencia sexual o de género, y preguntarse por sus límites y sus alcances. Llevar a cabo una crítica queer es encontrar en las imágenes esos datos que permiten además reproducir (o no) la multiplicación del capital.
3. Este nombre de una cadena de supermercados en Estados Unidos especializado en la venta de productos orgánicos se relaciona con las líneas verdes de productos Bio en Europa. Ambas líneas podrían remitir a la idea, no sólo de un alimento "entero", sino también de una vida entera, es decir, en términos biopolíticos, una vida digna. 


\section{Q Bibliografía}

»Alderson, D. (2016). Sex, needs \& queer culture. From liberation to the post-gay. Londres: Zed Books.

"Cangi, A. (1996). Lógicas del desperdicio. En Cangi, A. y Siganevich, P. (comps.), Lúmpenes peregrinaciones. Ensayos sobre Néstor Perlongher, pp. 76-88. Rosario: Beatriz Viterbo Editora.

"Dahbar, M. V., Canseco, A. y Song, E. (comps.) (2017). ¿Qué hacemos con las normas que nos hacen?: usos de Judith Butler. Córdoba: Sexualidades doctas.

»Deleuze, G. (1995). Optimismo, pesimismo y viaje (Carta a Serge Daney). En Conversaciones 1972-1990, pp. 114-131. Valencia: Pre-textos. Págs.

» Falconí Trávez, D., Castellanos, S. y Viteri, M. A. (eds.) (2013). Resentir lo queer en América Latina: diálogos desde/con el Sur. Madrid: Editorial Egales.

"Santiago, S. (2008). Intensidades discursivas. En O cosmopolitismo do pobre, pp. 125-133. Minas Gerais: Editora UFMG.

"Rancière, J. (2013). El espectador emancipado. Buenos Aires: Manantial. 